\title{
Ancient art, rhetoric and the Lamb of God metaphor in John 1:29 and 1:36
}

Author:
Lilly Nortjé-Meyer ${ }^{1}$
Affiliation:
1Department of Religion
Studies, University of
Johannesburg, South Africa
Correspondence to:
Lilly Nortjé-Meyer
Email:
lillynm@uj.ac.za
Postal address:
PO Box 524, Auckland Park
2006, South Africa
Dates:
Received: 12 Jan. 2015
Accepted: 20 Feb. 2015
Published: 03 July 2015
How to cite this article:
Meyer, L.N., 2015, 'Ancient
art, rhetoric and the Lamb of
God metaphor in John 1:29
and 1:36', HTS Teologiese
Studies/Theological Studies
71(1), Art. \#2889, 8 pages.
http://dx.doi.org/10.4102/
hts.v71i1.2889
Co 2015. The Authors.
Licensee: AOSIS
OpenJournals. This work is
Lonser the Creative
Littribution

Read online:
Biblical scholars have given diverse explanations for the Lamb of God metaphor in John 1:29 and 1:36. Most scholars are of the opinion that 'amnos' refers to the Passover lamb. This explanation is not obvious from the context of the Fourth Gospel. To understand the metaphor 'lamb' or 'amnos' of God, one should understand the transferable meaning of the figure or image. In this comparison, only the vehicle, namely the lamb, is given. What and who the lamb is stays open. It can be anything within the limits of the other story elements that have the same qualities as a lamb. To uncover the communicative dynamics of the metaphor, the exegete must have insight into the meaning and function of the original metaphor. Rhetoric provides a clue for the interpretation of the metaphor, namely that it is a Lamb of God. Within the pericope other rhetorical clues like antithesis and varietas are also provided. These clues are important but do not explain the image of the lamb. In this study, these problems will be considered via another medium, namely Hellenistic art and images and their penetration into Judaism and Christianity during the 1st century CE. Hellenistic and biblical images will be used to give an alternative interpretation of the metaphor of the Lamb of God.

\section{Introduction}

The aim of this article is to indicate that the metaphor of the Lamb of God, like the metaphor of the son, is to be viewed in terms of the relationship between God and Jesus.

The image of the amnos in John 1:29 and 1:36 is not the most important metaphor in the Fourth Gospel. Although it has become one of the most discussed metaphors not only in this Gospel but of the entire New Testament, there is still no consensus amongst scholars about the symbolic meaning and background of this metaphor.

Christopher Skinner (2004:89-104) summarises the nine most common views on the subject. He divides these views into two groups: those who interpret the metaphor in terms of the theology of atonement, and those who do not. Below follows a brief summary of the different views. Skinner has discussed the advantages and disadvantages of the different views and therefore I will not repeat this in detail.

\section{The most common views on the background of the lamb The lamb of the daily sacrifices (tamid)}

This daily sacrificial offering of two lambs (morning and evening) in the tabernacle and later in the temple was part of the communal life and worship of the Israelites (Ex 29:38-42). The lambs were to be physically unblemished. This was to reflect the otherness and holiness of YHWH. According to Skinner (2004:90), this 'view is attractive because it offers a theologically sophisticated referent behind the "Lamb". This referent is the absolute perfection of Jesus, and the cross of Christ (his death) is presented as both a sacrifice for sin and as a vicarious experience providing access to God. Other Old Testament offerings that fall into the same category and can be implicated are the kebasim (Nm 29:1-29:4; 29:8-29:10), the burnt offerings ( $\mathrm{Nv} 1: 10$ ), the peace offering (Lv 3:7-3:9), and the sin offering ( $\operatorname{Lv} 4: 32)$.

\section{The scapegoat (Lv 16)}

According to Leviticus 16:6-16:10, part of the requirements for the Day of Atonement (Yom Kippur) is the offering of a scapegoat. Although the scapegoat has a strong association with atonement, it can be explained only in the light of the crucifixion of Jesus, although the scapegoat was not a lamb. According to Skinner (2004:92-93), no modern scholar supports this view. 


\section{The gentle lamb of Jeremiah 11:19}

The gentle lamb actually refers to the prophet and refers to unsuspecting innocence and meekness in the face of suffering. This could indicate the 'Lamb of God which takes away the sin of the world' (Jn 1:29), but it is unlikely that this was the ultimate idea of John the Baptist's Lamb of God. In addition, it can be said that the LXX translates the gentle lamb as arnion (ram), a metaphor used in Revelations and not in the Fourth Gospel (Skinner 2004:93).

The guilt offerings are mentioned in Leviticus 14:12-14:13 and Numbers 6:11-6:12 and indicate the removal of guilt of the priest who has to perform a purification ritual and are therefore associated with the removal of sin. The problem with the guilt offerings was that the sacrifice was not always a lamb but more often a bull or a goat (Skinner 2004:94).

The Aqedah of Genesis 22:8 refers to the sacrificial animal God provided as a substitute for the offering of Isaac. This image corresponds with a few aspects of the crucifixion of Jesus: for example, he carried the wooden cross as Isaac carried the wood for the sacrifice; he laid down his life to receive it back again, as Isaac did symbolically; and then the animal as a substitute offering. However, in Isaac's case it was a ram and not a lamb. The Aqedah also does not refer to the removal of sin (Skinner 2004:95).

\section{The lamb led to be slaughtered in Isaiah 53:7}

This is one of the most significant images to regard as background for the Lamb of God. The New Testament writers have referred to especially Isaiah as a useful prophecy to indicate Jesus' substitutionary death. In Acts 8:35, when the Ethiopian eunuch asks Philip to explain Isaiah 53:7, he applied this prophecy to Jesus. Although this image occurs in one of the Servant Songs in Isaiah, and the suffering servant of the Lord is one of the images applied to Jesus' substitutionary life and death, scholars like Skinner (2004:96) are of the opinion that 'there was no concept in Hebraic thought of a suffering Messiah'. Brent Sandy (1991:447) also denies that an atoning meaning is attached to amnos.

\section{The lamb as paschal imagery}

This view gets the most support from scholars such as Raymond Brown ([1966] 1982:58-62) and Margaret Davies (1992:234; 305). Dorothy Lee (2011:13-28) has discussed this view in a recent article by arguing convincingly in favour of the Passover as an important motive for the narrative and theological structure of the Fourth Gospel. She also argues for the incorporation of other Old Testament concepts associated with the temple and the cult into the Passover imagery. As the narrative develops, she argues that the Passover develops into its own metaphorical field to become a major symbol in the Fourth Gospel. A major problem with this view is that the Passover animal was not always a lamb, but could also be a sheep or goat (cf. Ex 12:5) and that the term pasga is used nine times in this Gospel but only once in John 18:28 in connection with the sacrifice itself (Skinner 2004:98). A further important problem is the association of the lamb with the substitutionary death of Jesus and the taking away of sin. Although the Passover animal was associated with liberation and suffering, it was not seen as a substitutionary offering.

The apocalyptic lamb (arnion) in Revelations 7:17 and 17:14: Charles H. Dodd ([1953] 1980:230-238) as the main exponent of this view sees the Lamb of God as equivalent to 'King of Israel'. He wants to indicate with this construction that John the Baptist wanted to present Jesus as the Messiah and therefore identifies the amnos with the triumphant, conquering and horned lamb in Revelations, namely the arnion. In Revelations 5:6-5:14, the slain lamb (arnion) has returned from death and is receiving worship; he also exercises wrath and power ( $\operatorname{Rv} 6: 15-6: 17)$; is the shepherd of God's people ( $\operatorname{Rv} 7: 17)$; stands triumphant on Mount Zion ( $R v$ 14:1); overcomes opposition ( $\operatorname{Rv} 17: 14)$; and eventually establishes his reign on earth as representative of God ( $R v$ 22:1). The first objection to this interpretation is that the word for the apocalyptic lamb is arnion and not amnos, as the announcement of John the Baptist indicated. In the Fourth Gospel several words are used for lamb, namely amnos, arnion, pasga and probation, and we must therefore conclude that the evangelist used amnos to indicate something other than arnion. Second, Revelations was probably written much later than the Gospel, and therefore Skinner thinks it would be anachronistic to use the image of the arnion in Revelations to explain the amnos in the Fourth Gospel. Dodd, however, reasons that the evangelist could have taken the idea of the apocalyptic lamb from the Intertestamental apocalyptic literature and associates the Lamb of God with the same images. Skinner (2004:101-102) thinks this is unlikely because of the 'consistent focus of the Evangelist on the redemption provided in Christ'.

\section{The servant from Isaiah 53 (Ac 8:32)}

The amnos as the servant of $\mathrm{YHWH}$ was first argued for by C.J. Ball (1909:92-93) in the early 1900s. Since then a few prominent Johannine scholars, for example Walter Zimmerli and Joachim Jeremias (1957:82), have supported this view. According to this interpretation, an Aramaic expression, 'servant of the Lord', underlies the genitive combination of the Greek ho amnos tou theou and was mistranslated over time as 'Lamb of God'. This view indicates that the Aramaic term talya is understood in the sense of the Hebrew talya, which can mean lamb, boy or servant (Koehler \& Baumgartner 1953:352). This view further postulated that talya was mistranslated as amnos (lamb) instead of pais (servant), and resulted in an incorrect Greek rendering (Skinner 2004:99-100). The main concerns are that the LXX never translates talya into amnos, and no examples of talya as a rendering of ebed (servant) are presented (Brown [1966] 1982:61). In conclusion, lamb seems not to be a mistranslation of servant. However, only the possibility of the Old Testament background of 'servant 
of the Lord' or ebed YHWH is taken into consideration, and no other influences from the surrounding cultures that could instigate a cross-translation of servant or son with lamb are provided. This point of view is strengthened in the discussion that follows.

Other theories in connection with the 'servant' explanation are the ambivalent usage of words, for example, the Aramaic word immera (lamb) (pronounced also imra [word]) and in Hebrew imerah (word) (also pronounced imra) are both presented by amnos (Negoitsa \& Daniel 1971:24-37). Unfortunately, nothing in the Gospel points to an understanding of the servant of the Lord as the Lamb (amnos) of God (Skinner 2004:100).

I have indicated in a previous publication that the context of John 1:29-34 does not exclusively support a paschal lamb interpretation of amnos. Therefore, a different route is taken, namely a discussion of the father-son and shepherd-lamb imagery as motivation for the amnos metaphor (Nortjé 1996:141-150).

\section{The macro-metaphor in the Fourth Gospel}

I will not discuss the metaphor as literary phenomenon as such. Many scholars, for example Jan van der Watt (1999) and Gerhard van den Heever, have done this (1992:89-100). Van den Heever has also discussed other Hellenistic metaphors used by the evangelist. Instead, I follow Norman Peterson (1993:10) by taking the following working definition of metaphor: 'Metaphor is that figure of speech whereby we speak about one thing in terms of which are seen to be suggestive of another' ${ }^{1}{ }^{1}$ Utterances have their meaning in a communicative context: in what is expressed by the author or speaker and what the reader or hearer understands. Their meanings are not determined by an external standard, but by the understanding of the hearer or interpreter. The following discussion is an interpretation of the Lamb of God in terms of other suggestive imagery in the Fourth Gospel.

Several elements in the pericope of John 1:29-34 indicate the background against which this pericope as a whole and, more specifically, the metaphor of the lamb should be interpreted. The pericope forms an integral part of the rest of the Gospel and the metaphor on the micro and meso level should be applicable on the macro level.

Various scholars see different images as the most essential image in the Gospel against which the other images should be interpreted. Van den Heever (1992:97-99) identifies the concept of life as central in the Gospel and Van der Watt (1999:308) sees the family imagery as the most essential and pervasive imagery. According to him, there are two groups of metaphors, namely birth-life and father-son,

1.See Soskice (1984:87-129) for a more technical discussion of metaphor and religious language. which form the basis for the development of the family imagery.

Both these groups of metaphors are important in the first chapter of the Gospel. God is portrayed as the CreatorKing, but also as the Father. He is the Father of Jesus, but also the Father of the believers. The close relationship and unity between Father and son is strongly emphasised in the Gospel. The son is in the bosom of the Father; he knows the Father and had seen the unseen God. They are one in thought and action, and have the same Spirit. The son communicates freely with the Father and the Father knows what the son wants, the son obeys the Father and can do nothing of his own accord. The Father stays with and in the son, and the son is never alone even when he lays down his life (Culpepper 1983:107).

The Father sends his son on a mission to the world. This includes that he must lay down his life for the believers so that they can become children of God and part of the family of the Father.

The family is the rich family of the Creator-King. This King owns a house and property, and there are sheep, fish, wine and lands ready for harvest. Because it is the family of the Creator-King, forensic activities can be expected: the King judges according to belief or unbelief in the son of the Father (Jn 3:17-21) (Van der Watt 1999:315-316).

This imagery serves as background for the appearance of the One coming from above, which is mentioned by name only in John 1:17.

\section{Introducing the One from above (Jn 1:1-18)}

The overall strategy of the implied author is to construct the prologue in such a way that it serves as a comprehensive introduction to the basic ideological perspective presented in the Gospel. The most important perspective is the identity of Jesus: who he is, what he says and how other people react towards him. Dialogue about this question is repeated by John the Baptist, the followers of Jesus and his opponents. The prologue also serves to introduce other 'secondary' aspects, for example the characterisation of God (Tolmie 1998:57-75) and specifically the relationship between Jesus and God (Culpepper 1983:107).

The prologue is a careful but somewhat indirect introduction of Jesus. He is spoken of as the logos, light and life. He is mentioned by name only in John 1:17. At the end of the prologue, the implied reader knows his origin, his status and the main significance of his life. The implied reader also knows what his relationship with God is. Like his identity question, the question of his relationship with God occurs throughout the Gospel in discussion with John the Baptist, his opponents, his disciples and other characters.

When the implied author refers in John 1:18 to God as the Father and to Jesus as the son, it prepares the implied reader 
for the kind of relationship between the logos and God. This father-son image forms the basis for the development of the father-son imagery in the rest of the Gospel and the orientation according to which the family image is developed.

\section{John the Baptist is not the One (Jn 1:19-28)}

The introduction continues with the witness of John the Baptist on two consecutive days. The implied author uses John as first witness because he was not a follower of Jesus ('I also didn't know him'; Jn 1:31; 1:33) and because the Jews have considered him as a prophet (Jn 5:35) (Neyrey 1988:12). The implied author also uses forensic elements to prove the identity of John and Jesus. After the first introduction, the implied reader is convinced that John is an independent and trustworthy witness and that he is not the One who is coming from God to make God known (cf. Jn 3:28-30; 9:22).

\section{The One is the Lamb (amnos) of God (Jn 1:29 and 1:34)}

The second introduction is presented as the first appearance of the One in public. This is where the story of the appearance of the One started and is the beginning of the exploration of his identity.

This is the first time that 'the One' appears in public and can be seen. 'Seeing' (Jn 1:29; 1:32; 1:33; 1:34) and 'did not know him' (Jn 1:31; 1:33) are topics that move the narrative forward from seeing Jesus merely coming towards him 'as an ordinary man' to seeing what is happening to him and seeing him as the son of God. This establishes the relation between seeing, truth and belief that is explored in the rest of the narrative (cf. In 20:29; 'Because you have seen me, you have believed; blessed are those who have not seen and yet have believed'). However, John the Baptist's faith is not further developed in the Gospel (Davies 1992:38).

John the Baptist starts his witness by identifying the One as the Lamb of God. His essence is indicated as pre-existent (Jn 1:30), and his function is to baptise in or with the Holy Spirit because he has received the Spirit of God (Jn 1:33). The witness, knowledge and insight of John come to a climax when he identifies the One as the Son of God. The family image is expressed by the son-God image. God is the son's Father (Jn 1:18) and God has given him his Spirit (Jn 1:32). Therefore, he and the Father have the same Spirit (Van der Watt 1999:332). It is not only about the identity of the One, but also about his relationship with God, as Father.

Most scholars see the metaphorical use of 'lamb' in this context attributes qualities associated with only the word 'lamb' to refer to Jesus and not the qualities associated with the lamb 'of God' (Lee 2011:14). The genitive expresses possession and may mean either something for God or something belonging to God. In the light of the aforementioned conclusion, the lamb belongs to God in the same way as the son belongs to God and not as something that is given to him. Francois Tolmie (1998:68) also suggests that the basic message of Jesus as the Lamb of God in terms of the characterisation of God is to be viewed in terms of the relationship between God and Jesus. I would therefore rather seek the background information of the lamb metaphor against the same background as the son metaphor. The 'vehicle' lamb and the 'vehicle' son have the same tenor, namely God. 'Son' is a relational term and implies the father-son imagery. If the same relational principle (which is already indicated in the pericope), is applied to the lamb, the lamb metaphor instead implies the shepherd-lamb imagery. In John 10, we already have the image of the son as the good shepherd who is caring, protecting the sheep, and willing to lay down his life for them. I would therefore rather look for the background information of the lamb and son metaphors in John 1:29 and 1:34 in the shepherd image, namely God as the Shepherd and the son as the lamb. In this case the qualities of the relationship between the lamb and God, say as the shepherd, are transferred to Jesus and not only the qualities of $a$ (paschal or sacrificial, etc.) lamb.

\section{Motivation}

The motivation for the shepherd-lamb (flock) and father-son (family) image as the background of the lamb metaphor is as follows.

\section{The Fourth Gospel}

The metaphors of the shepherd and the son are already part of the imagery in the Fourth Gospel. In John 10, Jesus is portrayed as the shepherd who looks after (Jn 10:16; 10:28-10:29), provides and cares (Jn 10:10) and dies for the sheep (Jn 10:11; 10:17-10:18). Several other themes, for example, Jesus will be left alone (to die), but the Father will be with him in power (Jn 16:31-16:32), correspond with the shepherd and the sheep imagery, although it is not explicitly stated (Van der Watt 1999:66-67).

It is also evident in the Gospel that the unity between the Father and the son indicated in the prologue is progressively defined through his mission. The highest claim that Jesus has for himself is that he and the Father are one and that the son is doing the works of the Father (Jn 5:19-5:26; 10:30; 36; 38; 14:9) (Culpepper 1983:108). This unity between Father and son is also reflected by the relationship between the son and the believers. As the Father educates (Jn 5:19ff.; 8:28), sends (Jn 3:34; 5:36; 17:4), loves (Jn 3:35; 5:20; 10:17; 15:9), cares for and protects (Jn $8: 29 ; 16: 32)$ the son, in the same way the son educates (Jn 6:59; 7:14; 7:28; 8:2; 18:20), sends (Jn 17:18; 20:21), loves (Jn 14:31; 15:9), cares for and protects (Jn 14:18; 10:28,29; 17:12) the children of the family of the Father. Tolmie (1998:66) indicates that, in John 10, God is almost continuously characterised as the Father of Jesus, and his relationship with Jesus is dominant. In this light, it is possible that the implied author used the lamb and son metaphors in John 1:29 and 1:34 as preparation and indication for the Father and the shepherd metaphors in John 10 (cf. Jn 8:29; 16:32). The image 
of the shepherd and the lamb, implicitly expressed in the Lamb of God metaphor, is narratologically extended to the sheep farming imagery (that also occurs in Jn 21:15-21:17) and is transferred to Jesus as the good shepherd.

\section{Old Testament}

The Old Testament also provides a background for the fatherson and shepherd-lamb imagery. The absolute form 'the Son of God' as is expressed in the Fourth Gospel is not an Old Testament concept. In Exodus 4:22, Israel is instead called God's son or 'first born', and in Deuteronomy 32:6, YHWH is called their Father. This theme is reiterated constantly in prophetic preaching (cf. Is 63:16; 64:8; Mal 2:10) (Brown [1966] 1982:364). This reflects a special relationship between YHWH and Israel. In the eastern family the son is the heir of the father, and is thus the object of special love, attention, training and protection (cf. Hs 11:1-4). According to Pryor (1992:129), it is essentially a relational term. From a Johannine perspective, sonship is expressed by obedience and devotion, in contrast to a history of disobedience by Israel (Davies 1992:129).

The image of God as a shepherd is also a well-known Old Testament image. During the earlier period of Israel's seminomadic existence, God alone was viewed as shepherd and protector (cf. Gn 48:15; 49:24; Dt 26:5-26:8; Jr 13:17; Mk 7:14). In Ezekiel 34:20, God acts as the shepherd who cares for and looks after his people. He also provides a shepherd who will also care for them, namely David (34:23-34:24) (Barrett 1972:310). ${ }^{2}$ God also acts as a shepherd-judge: 'I will shepherd the flock with justice' (Ezk 34:16) (Vancil 1992:1189). God is also portrayed as a shepherd who leads the people to safe pastures (Ex 15:13; 15:17), and holds to his bosom animals that cannot keep up (Is 40:11; Ps 28:9). This reflects the attitude of ancient Israelites, namely that land and animals were treated in the same way they cared for themselves (Matthews \& Benjamin 1993:58).

Psalm 23 is especially applicable in this context because God is depicted as a shepherd who is loyal and devoted. It is easy to find similar themes from this Psalm in the Fourth Gospel and especially in connection with Jesus. The caring elements in Psalm 23 are present in the Father-son image in John; God as his Father loves and cares for him - even in the face of death (Ps 23:1-4; Jn 8:29; 16:32); Jesus dies at the hands of his enemies (Ps 23:5; Jn 11:53); he was anointed by the Holy Spirit (Ps 23:5; Jn 1:32); and he is going to the house of his Father to prepare a place for his followers (disciples and believers) (Ps 23:6b; Jn 14:2). This makes the shepherd imagery more obvious as background for the interpretation of the lamb metaphor in John 1:29.

\section{Gnostic background}

Various scholars have argued for a Gnostic influence on the Fourth Gospel. The Father-son relationship and redemption

2.In non-Jewish circles gods and great men were also described as shepherds: Anubis, Attis, Yima, Zarathustra, Marduk, and the Phrygian gods. Babylonian kings and Greek heroes (Agamemnon) were spoken of as herdsmen of their people. Apollonius of Tyana spoke of his disciples as his flock. are of special importance. It seems that the Father-son designation and relationship is not simply borrowed from the Fourth Gospel, but the Gnostic idea of father-son image could also have influenced the evangelist (Schnackenburg 1980:181-182). ${ }^{3}$

The most significant Gnostic influence on the New Testament is the Corpus Hermeticum, emerging from the 2nd to the 4th and/or 5th century CE. Most of the 17 tractates are ascribed to Hermes Trismegistos (thrice-greatest), a Graeco-Egyptian deity. It is a syncretism between Hermes the Greek messenger and shepherd god and Thot, his Egyptian counterpart, who contributed the epithet. ${ }^{4}$

Although each tractate has its own concerns, the main point of the Hermetic texts is to provide a way for human salvation from the empirical world. In the Poimandres (Corp. Herm. 1) the logos coming forth from the nous is called 'son of God' (6); and God is called the father of all $(21 ; 27)$; God and father (21); and father God (30). In CH 8 (about rebirth) the Gnostic is to become, through the revelation of Hermes, a son or child of God (Schnackenburg 1980:183). CH 4 refers to a dipping (baptism) into the 'basin of mind' sent down from heaven. $\mathrm{CH} 13$ takes the reader through a complete regeneration and rebirth of the individual, which are necessary for true understanding and salvation to take place. The disclosure of knowledge about the nature of the universe and salvation occurs in the form of a dialogue in most of the tractates. Hermes is usually the hierophant (manifestation of God and Asclepius; $\mathrm{CH}$ 2, 4, 5, 6, 8, 9, 12, 13, 14) and Hermes's son Tat (Thot) or Asclepius serves as receiver of the knowledge. In $\mathrm{CH}$ 9, God himself imparts knowledge to Hermes (Trumbower 1992:157).

It seems evident that the evangelist was working with similar presuppositions and along similar lines to those of the Hermetic authors. In both the Fourth Gospel and the Hermetica, the following themes appear: speculative cosmologies, various types of dualism, individual salvation, sacraments, knowledge of God (Jn 17:3), God as life and light, divine begetting, rebirth, mediation between God and humankind is through a logos or heavenly man (Barrett 1972:32) or the revealer and redeemer as the 'son of God' (Schnackenburg 1980:183-184). Turner (1991:51) also gives interesting similarities between Jesus as the shepherd in John 10 and Hermes, but indicating that Jesus was obviously more important than Hermes.

There are no literary dependencies, but it seems that the Johannine text (especially the prologue and the introduction

3.Schnackenburg (1980) argues that the Ode 23 of Solomon shows knowledge of the Gnostic myth which, because of the peculiar imagery used, could not have been transmitted through the Fourth Gospel. It is also true of the Gospel of Truth, which is closely related in many aspects to the Odes of Solomon. Barrett (1972:31) also finds Gnostic systems (Christian and non-Christian sources) were influenced by religions Gnostic systems (Christian and non-Christian sources) were influenced by religions of Salvation (with its many variations). See also C.H. Dodd (1954-1955:54-57). Turner (1991:50) is also of the opinion that 'The myth of the pre-existent divine wisdom descending from the divine world in search of her own, underlies much, and perhaps most, of the Fourth Gospel, not only its prologue'. See also J.A. Brant (1998:199-211) for Greek novel influence.

4.The tractates reflect the adaptation of Greek philosophy to late Egyptian religious thought, and therefore reflect the influence of Egyptian gods and cults. 
of the One coming from above 1:29-1:34) and the Hermetic texts are representative of a common religious thought and milieu.

\section{Hellenistic and Christian art and sculpture}

Another argument is that it is evident that the early Christians had chosen images and symbols that were common to the Old Testament and the pagan environment they were living in. The subject and themes of the early Christian iconography give us information about the new factor of universal significance early Christian art represented (Henderson 1985:3-12; Huyghe 1968:23). ${ }^{5}$ This is illustrated by the images of paintings found in Dura-Europus in Syria and the catacomb paintings in Rome (dating 2nd-3rd century CE). Amongst frequently recurring motifs in early Christian art which have been taken from the pagan world are the peacock, the dove, the athlete's palm, the fish, the seasons, solar pantheism, the vintage feast which was part of the Dionysiac funerary cult (Van den Heever 1992:97-98) and the shepherd who carries a lamb across his shoulders. Gough (1973:18) said that this image is so familiar in early Christian art that it is easy to lose sight of its pagan origin.

In Greece and even throughout the Graeco-Roman world, Hermes Criophorus (the ram-carrier) was a favourite subject for sculpture, and his adaptation by Christians would probably have passed unnoticed by the pagans.

Hermes is a perfect example of the pluralistic nature of the Greek divinities. ${ }^{6}$ He was born on Mt. Cyllene in Arcadia as the son of Zeus and the nymph Maia (daughter of the titan Atlas). He began his divine career as the power of spirit residing in the roadside cairn, the stone heap or herma, which served as the marker of boundaries, entrances and graves. He then rose from the rocks that held him captive and came to surmount them in the form of a herm, a stone (Martin 1992:155). On the day of his birth, he killed a tortoise and made the world's first lyre out of its shell. The day after his birth, he stole the oxen of Admetus which Apollo, his halfbrother, was guarding. Apollo discovered that Hermes was the thief and Hermes gave him the lyre to win him over. Apollo accepted the gift and gave Hermes a shepherd's crook. This made him the protector of shepherds. When Hermes grew up, he became the official messenger and servant of the gods. Zeus often used him as a mediator in his various love affairs.

However, Hermes was much more than that. He also had the role of escorting the dead to the underworld. He had the

5.George Henderson (1985:3-12) has also utilised the art of the sculptured Ruthwell Cross to interpret biblical and ecclesiastical liturgy.

6.The sources for the Greek myths are a mixture of written texts, sculpture and decorated pottery. Information about stories that circulated orally has to be reconstructed indirectly by inference and guesswork. The Greek religion was polytheistic, and the culture within which it was practiced was pluralistic. The stories about the origin and actions of divinities varied widely, and depend on the stories about the origin and actions of divinities varied widely, and depend on the
context in which they were told. The stories emerged in different types of narratives, context in which they were told. The stories emerged in different types of narratives,
for example, epic, tragedy or comedy. They portrayed widely different and even for example, epic, tragedy or comedy. They portrayed widely different and even
conflicting aspects of the Greek divine world. Moreover, there were geographical conflicting aspects of the Greek divine world. Moreover, there were geographical
variations too. A god might have one set of characteristics in the city or region, and variations too. A god might have one set
quite different characteristics elsewhere. power to cross all kinds of boundaries. He was the patron of merchants, the protector of traders, herdsmen and seamen, of good luck and wealth, and of thieves and pickpockets, and he was renowned for his mischief-making. He was also the god of roads and fertility, and the deity of athletes. He protected gymnasiums and stadiums and had magical powers over sleep and dreams (Clayton 1990:100).

He was also known as Hermes Criophorus, ${ }^{7}$ and this is of interest to us. This motif comes from the ancient moscophore prototypes of Hermes criophore (Duchet-Suchaux \& Pastoureau 1994:164). Sculptures of Hermes Chriophorus were popular and were found throughout the GraecoRoman world: for example, the Herodian harbour Caesarea in Israel (Finegan 1969:76), ${ }^{8}$ the Acropolis in Athens (4th century), and in Corinth (4th century). An important and interesting variation from Sparta of Hermes Criophorus is a depiction of him carrying the lamb on his arm and not on his shoulders (National Museum in Athens 460-450 BCE). This probably symbolises a lamb, which can easily be carried on the arm, and not a ram, which would have to be carried on the shoulders. The next important image of Hermes is one of him carrying the new-born Dionysus, the god of wine, on his arm. In the other hand, he is probably holding a bunch of grapes, which the infant god is trying to reach (Servi 1997:44).

These images have influenced the early Christian art in three ways. The first of these is in the good shepherd watching over his sheep. He stands or sits in the middle of the flock and is ready to protect them against any dangers (cf. 5th century mosaic in the Mausoleum of Galla Placidia in Ravenna). This theme is associated with Orpheus, a figure in the art of the paleochristian period as a symbolic 'likeness' of Christ. This image of the shepherd watching over the flock is a later image from the 5th century (Finegan 1969:76).

The second depiction is as a shepherd with a ram or sheep on his shoulders. This is illustrated by the paintings in Dura Europus c. 245, the catacombs of Priscilla, Domitilla and Callista in Rome. It seems that this motif figured in the very early Christian art (2nd-3rd century). It is easy to see the congruity between Hermes Criophorus and this image of Jesus as the good shepherd with a sheep on his shoulders. In Dura Europus symbols of deliverance are taken from the Old Testament and the New Testament where Adam and Eve and the serpent were a reminder of the fall of humanity and opposite them appeared the shepherd, the image of redemption. In early paintings and on sarcophagi the shepherd is portrayed against a background of trees and

7.The Arcadia district in the central Peloponnese in Greece was the home of Hermes Criophorus. In later literature Arcadia became the setting for poetic evocations of pastoral life. Whilst the actual terrain of Arcadia is harsh and mountainous, the idealised landscape is gentle and fertile, home to an uncorrupted community of shepherds and rustic deities ('Arcadia Mythology', Microsoft Encarta Encyclopaedia 2000).

8.According to Finegan (1969), the Hermes figure in Caesarea can be dated to the 5th century CE. According to him, it came from buildings that were built between the 4 th-7th century CE. A few inscriptions were found on the pavement, including Romans 13:3. Josephus (1981:331-332), on the other hand, mentions that there Romans 13:3. Josephus (1981:331-332), on the other hand, mentions that there
were temples, a palace, statues of gods and goddesses, and an agora. He also notes were temples, a palace, statues of gods and goddesses, and an agora. He also notes
that the streets were arranged according to the Hippodamian system, a typical Greek architechtural style. An inscription about Pilate is also found. This dates the Greek architechtural style. An inscription about Pilate
Hermes statue to the beginning of the Christian era. 
flowers, a pastoral setting which symbolises the paradise of the elect. According to Gough (1973:19-21), it symbolises the shepherd deliverance as prefigured also in Psalm 23.

The third image is of John the Baptist with the lamb on his arm. The oldest image of John with the lamb is found in Ravenna, Italy, and dates to the 3rd-4th or 5th-6th century CE. I have indicated in a previous publication that John with the lamb was already established very early (probably before the Constantine era) as a 'trademark' for him, whilst Peter is portrayed with a curled beard and hair and Paul with a pointed beard and bald head. It is noticeable that John is never portrayed with the lamb on his shoulders. The congruity between John the Baptist and Hermes as messengers with either the lamb or Dionysus on the arm is also noticeable. This is so especially when the similarities between Hermes as revealer and redeemer, also known as the son of god in the Corpus Hermeticum, and the similarities between Dionysus' wine feast and the Fourth Gospel are kept in mind (Van den Heever 1992:99).

\section{Conclusion}

The primary aim of this article is to indicate that the metaphor of the Lamb of God, like the metaphor of the son, is to be viewed in terms of the relationship between God and Jesus. The background of the commonplace element shared by the lamb and the son metaphors is God as Father and God as Shepherd. The same characteristics of God (as Father and as Shepherd) are found in the father-son relationship and the good shepherd metaphor in the Fourth Gospel. He who is the 'lamb' in John 1 became the shepherd in John 10. This background is also supported by the Old Testament images of God as Father and Shepherd of Israel and Israel as sons and as the flock of YHWH. The other supportive background and influence is the Hermetic literature, where Hermes the messenger and shepherd god is also portrayed as the son of god. There is also the congruity in early Christian art between John the Baptist with the lamb in his arms and the Hermes Criophorus image with either the lamb or the newborn Dionysus on his arm.

No literary dependencies or direct influence of these images on the Fourth Gospel or on the image of the Lamb of God can be proven, but it is indicated by many scholars that these images are representative of a common religious thought and milieu. Although Lee supports the Passover background of the Lamb of God imagery, she acknowledges that:

symbolism is not easily located in singular meaning but opens itself, by definition, to a 'surplus of meaning' that exceeds intentionality or design. In a religious context, it brings meaning into being, becoming the bridge between divine and human. In this sense, we might say that, while symbolism cannot easily be grasped, it can be approached. (Lee 2011:14)

The early Christian literature, art and images borrowed from the existing images from the Old Testament and the pagan world they were living in. It is arguable that the early
Christians laid one perception over another and that no single inter-textual reading of the metaphor can be taken as the background to the lamb metaphor; rather, they are likely to have combined images from the milieu in which they were living. To me, it seems that this is exactly what the evangelist did: he took images and material from the existing Christian traditions, the Old Testament and the pagan world and created his own images and message about Jesus.

I have not addressed the qualification of the lamb, namely he 'who takes away the sin of the world', but this attribution to the lamb emphasises the universalism inherent in the Fourth Gospel's central testimony, namely that the lamb takes away the sin of the world and not just that of Israel, inasmuch as the Father sent the son into the world to save the world (Jn 3:16-3:17). Commentators interpreting the lamb as the Passover lamb do not take the qualification 'the sin of the world' into consideration. To me, God remains the initiator who saves the world through his Son as the Lamb. This emphasises even more the idea that the author took images from various traditions to create his message about Jesus, especially if we take into consideration that the Gospel was probably written from Ephesus.

\section{Acknowledgements Competing interests}

The author declares that she has no financial or personal relationships which may have inappropriately influenced her in writing this article.

\section{References}

Ball, C.J., 1909, 'Had the Fourth Gospel an Aramaic archetype?', Expository Times 21, 92-93.

Barrett, C.K., 1972, The Gospel according to St. John: An introduction with commentary and notes on the Greek Text, SPCK, London.

Brant, J.A., 1998, 'Divine birth and apparent parents: The plot of the Fourth Gospel', in R.F. Hock, J.B. Chance \& J. Perkins (eds.), Ancient fiction and early Christian narrative, pp. 199-211, Scholars Press, Atlanta.

Brown, R.E. [1966] 1982, The Gospel according to John, vol. 1, Chapman, London.

Clayton, P., 1990, Great figures of mythology, Magna Books, Leicester.

Culpepper, R.A., 1983, Anatomy of the Fourth Gospel: A study in literary design, Fortress Press, Philadelphia.

Davies, M., 1992, 'Rhetoric and reference in the Fourth Gospel', Journal for the Study of the New Testament Supplement 69, 177-211.

Dodd, C.H., 1954-1955, 'The dialogue form in the Gospels', Bulletin for the John Rylands Library 37, 54-57.

Dodd, C.H. [1953] 1980, The interpretation of the Fourth Gospel, Cambridge Press, Cambridge.

Duchet-Suchaux, G. \& Pastoureau, M., 1994, The Bible and the Saints, transl. D. Radzinowicz-Howell, Flammarion, Paris.

Finegan, J., 1969, The archaeology of the New Testament: The life of Jesus and the beginning of the Early Church, Princeton University Press, Princeton.

Gough, M., 1973, The origins of Christian art, Thames \& Hudson, London.

Henderson, G., 1985, 'The John the Baptist panel on the Ruthwell Cross', Gesta 24(1), 3-12. http://dx.doi.org/10.2307/766928

Huyghe, R., 1968, Larousse encyclopedia of Byzantine and Medieval art, Paul Hamlyn, London.

Josephus, F., 1981, The complete works of Josephus, transl. W. Whiston, Kregel Publications, Grand Rapids.

Koehler, L. \& Baumgartner, W., 1953, Lexicon in Veteris Testamenti Libros, Brill Academic Publishers, Leiden.

Lee, D., 2011, 'Paschal imagery in the Gospel of John: A narrative and symbolic reading', Pacifica $24,13-28$.

Martin, H.M., 1992, 'Hermes (Deity)', in D.N. Freedman (ed.), The Anchor Bible Dictionary Vol. 3, Doubleday, New York. 
Matthews, V. \& Benjamin, D., 1993, Social world of ancient Israel 1250-587 BCE, Hendrickson, Peabody.

Microsoft Encarta Encyclopaedia, 2000, CD-ROM, Microsoft Corporation, Washington.

Negoitsa, A. \& Daniel, C., 1971, 'L'Agneau de Dieu est la verbe de Dieu', Novum Testamentum 13, 24-37. http://dx.doi.org/10.1163/156853671X00198

Neyrey, J.H., 1988, An ideology of revolt: John's Christology in social-science perspective, Fortress Press, Philadelphia.

Nortjé, S.J., 1996, 'Lamb of God (Amnos John 1:29): An explanation from ancient Christian art', Neotestamentica 30(1), 141-150.

Peterson, N.R., 1993, The Gospel of John and the sociology of light: Language and characterization in the Fourth Gospel, Trinity Press International, Valley Forge.

Pryor, J.W., 1992, John: Evangelist of the covenant people. The narrative \& themes of the Fourth Gospel, InterVarsity Press, Downers Grove.

Sandy, D.B., 1991, 'John the Baptist's "Lamb of God" affirmation in its canonical and apocalyptic milieu', Journal of the Evangelical Theological Society 43(4), 447-460.

Schnackenburg, R., 1980, The Gospel according to St. John, vol. II, Burns \& Oates, London.

Servi, K., 1997, Greek mythology, Ekdotike Athenon S.A., Athens.
Skinner, C.W., 2004, 'Another look at "The Lamb of God"', Bibliotheca Sacra 161, 89-104.

Soskice, J.M., 1984, Metaphor and religious language: Eco, semiotics and the philosophy of language, Indiana University Press, Bloomington.

Tolmie, D.F., 1998, 'The characterization of God in the Fourth Gospel', Journal for the Study of the New Testament 69, 57-75. http://dx.doi. org/10.1177/0142064X9802006903

Trumbower, J.A., 1992, 'Hermes Trismegistos', in D.N. Freedman (ed.), The Anchor Bible Dictionary, vol. 3, Doubleday, New York.

Turner, J.D., 1991, 'The history of religious background of John 10', in J. Beutler \& R.T. Fortna (eds.), The shepherd discourse of John 10 and its context, Cambridge R.I. Fortna (eds.), The shepherd discourse of John 10 and its context, Cambridge
University Press, Cambridge. http://dx.doi.org/10.1017/CBO9780511554865.004

Van den Heever, G.A., 1992, 'Theological metaphorics and the metaphors of John's Gospel', Neotestamentica 26(1), 89-100.

Van der Watt, J.G., 1999, 'Dynamics of metaphor in the Gospel according to John', PhD thesis, Deptartment of Theology, University of Pretoria.

Vancil, J.W., 1992, 'Sheep, Shepherd', in D.N. Freedman (ed.), The anchor Bible dictionary, vol. 5, Doubleday, New York.

Zimmerli, W. \& Jeremias, J., 1957, The servant of God, SCM Press, London. 